\title{
IMPLEMENTASI PEMBELAJARAN MENGGUNAKAN MEDIA POCKETBOOK BERBASIS DISCOVERY LEARNING TERHADAP KEMAMPUAN PEMAHAMAN MATEMATIS SISWA
}

\author{
Utin Desy Susiaty $^{1}$, Iwit Prihatin ${ }^{2}$ \\ ${ }^{1,2}$ Prodi Pendidikan Matematika, IKIP PGRI Pontianak \\ ${ }^{1,2}$ Jalan Ampera No. 88, Pontianak 78116, Indonesia \\ E-mail: d3or4f4ty4@gmail.com ${ }^{1)}$, iwitprihatin82@ gmail.com ${ }^{2)}$
}

\begin{abstract}
Abstrak
Tujuan penelitian adalah untuk mengetahui: (1) kemampuan pemahaman matematis siswa setelah diimplementasikan pembelajaran menggunakan media pocketbook berbasis discovery learning; (2) tingkat kefektifan media pocketbook berbasis discovery learning terhadap kemampuan pemahaman matematis siswa. Penelitian ini merupakan preeksperimental designs dengan rancangan one-shot case study. Populasi penelitian adalah seluruh siswa kelas VII MTs Hidayatul Muhsinin Kabupaten Kubu Raya. Sampel diambil dengan menggunakan teknik sampling jenuh. Teknik pengumpulan data yang digunakan adalah metode tes untuk data kemampuan pemahaman matematis siswa dan tingkat keefektifan media pocket book. Berdasarkan hasil penelitian dapat disimpulkan bahwa: (1) kemampuan pemahaman matematis siswa setelah diimplementasikan pembelajaran menggunakan media pocketbook berbasis discovery learning tuntas secara klasikal; (2) Pengembangan media pocket book berbasis discovery learning terhadap kemampuan pemahaman matematis pada materi aritmetika sosial kelas VII MTs Hidayatul Musinin Kabupaten Kubu Raya mencapai tingkat keefektifan dengan kriteria sangat efektif.
\end{abstract}

Kata kunci : pocketbook, discovery learning, kemampuan pemahaman matematis

\section{LEARNING IMPLEMENTATION USING POCKETBOOK MEDIA BASED ON DISCOVERY LEARNING ON STUDENTS' UNDERSTANDING ABILITY}

\begin{abstract}
The research objective was to find: (1) the ability of students' mathematical understanding after implementing learning using pocketbook media based on discovery learning; (2) the effectiveness of pocketbook media based on discovery learning on students' mathematical understanding abilities. This research is a pre-experimental design with a one-shot case study design. The study population was all VII grade students of MTs Hidayatul Muhsinin, Kubu Raya Regency. Samples were taken using saturated sampling techniques. The data collection technique used is the test method for data on students' mathematical understanding abilities and the effectiveness of pocket book media. Based on the results of the study it can be concluded that: (1) the ability of students' mathematical understanding after implementation of learning using pocketbook media based on discovery learning is completed in a classical manner; (2) Development of pocket book media based on discovery learning on the ability of mathematical understanding in class VII social arithmetic of MTs Hidayatul Musinin in Kubu Raya Regency achieves a level of effectiveness with very effective criteria.
\end{abstract}

Keywords: pocketbook, discovery learning, mathematical understanding skills 


\section{PENDAHULUAN}

Proses, perbuatan, dan cara memahami merupakan definisi dari pemahaman. Kegiatan belajar dan berpikir adalah tujuan akhir dari pemahaman. Tingkat kemampuan seseorang dalam memahami suatu definisi atau konsep, situasi serta kenyataan yang diketahuinya merupakan pemahaman dalam proses pembelajaran. Bukan hanya hapalan secara verbalitas, tetapi juga memahami konsep dari masalah atau kenyataan yang dipertanyakan, maka operasionalnya dapat membedakan, mengubah, mempersiapkan, menyajikan, mengatur, menginterprestasikan, menjelaskan, mendemonstrasikan, memberi contoh, memperkirakan, menentukan, dan mengambil keputusan. Pemahaman lebih tinggi satu tingkat dari hafalan. Kemampuan menangkap suatu makna atau arti dari suatu konsep diperlukan pemahaman serta adanya hubungan atau keterkaitan antara konsep dan makna atau arti dari suatu konsep. Seseorang mampu mengkonstruksi makna dari pesanpesan pelajaran seperti komunikasi lisan, tulisan, grafik, dan mampu membangun hubungan antara pengetahuan baru diintegrasikan dengan skemata kognitif yang sudah dimilikinya dikatakan bahwa seseorang tersebut memahami sesuatu (Moreno, 2018:1402).

Pembelajaran matematika yang tidak efektif merupakan masalah yang sangat menonjol yang dihadapi dalam pembelajaran matematika secara umum khsususnya yang berhubungan dengan pemahaman dalam pembelajaran matematika. Adapun pemahaman dalam pembelajaran matematika yang dimaksud adalah kemampuan pemahaman matematis. Kemampuan yang sangat penting dimiliki siswa dalam belajar matematika merupakan kemampuan pemahaman matematis (NCTM, 2000; Zulkardi, 2003; Karim, 2011). Kemampuan pemahaman matematis berkaitan dengan kemampuan siswa dalam memahami suatu konsep. Siswa dapat mencapai tujuan pembelajarannya apabila mereka dapat memahami konsep dengan baik (Putra, dkk., 2018:19). Sehubungan dengan kemampuan pemahaman matematis siswa, peran guru dalam menyampaikan materi pun sangat berpengaruh terhadap keberhasilan pencapaian pemahaman matematis siswa. Seperti siswa kelas VIII MTs Hidayatul Muhsinin yang masih mengalami kurangnya kepemilikan pemahaman matematis pada materi aritmetika sosial. Hal ini dibuktikan pada hasil pra observasi terhadap guru pelajaran matematika yang mana beliau mengajar kelas VII dan VIII di MTs Hidayatul Muhsinin Kabupaten Kubu Raya. Dalam wawancara yang dilakakukan pada saat itu, guru pelajaran matematika tersebut menyatakan bahwa kepemilikan pemahaman matematis peserta didik dalam memecahkan soal matematika masih kurang, dimana sebagian siswa hanya mampu menghafal rumus-rumus dengan baik, dan mereka belum memahami konsepnya dengan benar. Hal tersebut terlihat dari siswa yang hanya mampu mengerjakan soal yang sama dengan soal contoh yang diberikan, terlebih lagi soal yang berbentuk cerita, seperti pada materi aritmetika sosial kelas VII yang mana peserta didik masih belum paham dalam mengaitkan antar konsep dalam materi tersebut dan mengalami kesulitan dalam memecahkan soal.

Berdasarkan pemaparan hasil wawancara yang didapat, penulis pun membuktikan keadaan pemahaman matematis siswa pada materi aritmetika sosial di kelas VIII, yang mana materi tersebut telah mereka dapatkan pada saat dibangku kelas VII dengan memberikan tes mengerjakan soal aritmetika sosial menggunakan beberapa indikator pemahaman matematis. Hasil pengerjaan peserta didik disajikan pada gambar 1 .

Hasil tes kemampuan pemahaman matematis yang penulis adakan di kelas VIII, soal yang diujikan tersebut memenuhi indikator pemahaman matematis seperti, kemampuan menyatakan kembali konsep yang telah dipelajari, kemampuan 
menerapkan konsep secara algoritma, kemampuan mengaitkan berbagai konsep dan mengembangkan syarat suatu konsep. Dari hasil pengerjaan siswa pada gambar 1 jelas bahwa terdapat permasalahan pemahaman matematis siswa pada materi aritmetika sosial di kelas VIII, meskipun materi tersebut sudah mereka pelajari pada saat dibangku kelas VII. Dari hasil pengerjaannya, diperoleh fakta bahwa siswa mampu memahami masalah yang dimaksudkan soal, bisa memaparkan syarat suatu konsep untung dan rugi, namun algoritma dan perhitungan pengerjaan siswa tersebut disimpulkan bahwa siswa masih belum paham dalam mengaitkan beberapa konsep yang ada yaitu konsep untung, rugi dan diskon sehingga penerapan konsep yang digunakan salah dan kasus yang ada di soal tidak terpecahkan secara tepat. Kondisi konsep demikian apabila terus dibiarkan akan berdampak buruk terhadap penerapan dikehidupan sehari-hari mereka terutama dalam kegiatan jual beli. Sehingga pemahaman konsep matematis siswa pada materi aritmetika sosial perlu diperbaiki dan dikembangkan. masih salah karena dari hasil ketiga
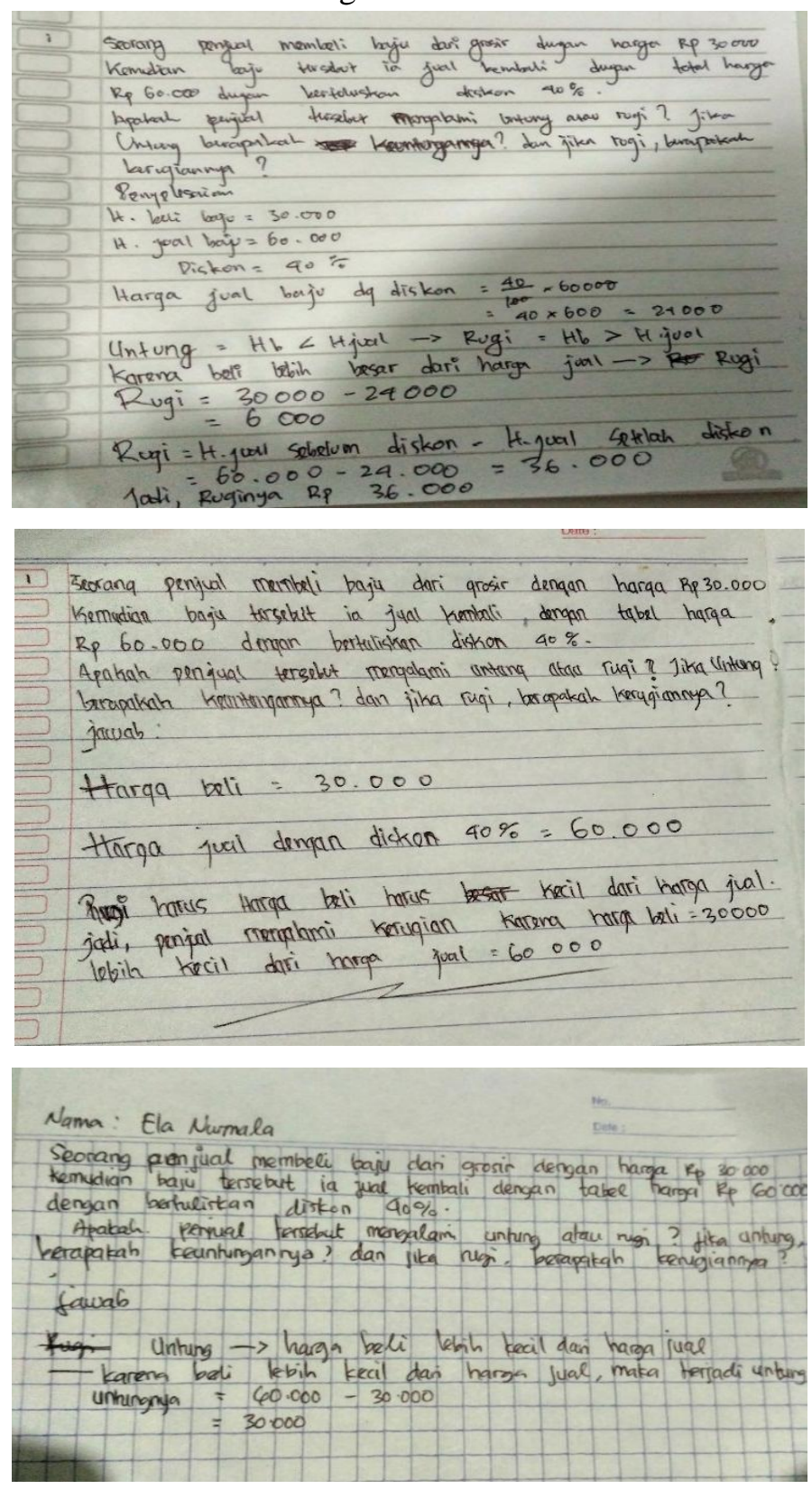

Gambar 1. Hasil Pengerjaan Siswa 
Kenyataan di lapangan menunjukkan bahwa dalam proses pembelajaran di kelas, guru masih menggunakan strategi pembelajaran biasa dan belum pernah menerapkan strategi pembelajaran yang sesuai dengan implementasi kurikulum 2013. Salah satu strategi pembelajaran yang digunakan dalam implementasi kurikulum 2013 dengan scientific approach adalah discovery learning. Discovery learning merupakan suatu pembelajaran yang melibatkan peserta didik dalam pemecahan masalah untuk mengembangkan pengetahuan dan keterampilan dari peserta didik tersebut dengan penemuan, peserta didik belajar secara intensif dengan mengikuti metode investigasi ilmiah di bawah supervisi guru (Anitah, 2009). Istiana, dkk (2015:67) menyatakan bahwa discovery learning dapat meningkatkan aktivitas dan prestasi belajar siswa, terutama untuk materi yang membutuhkan pemahaman konsep dan kemampuan matematis yang baik.

Discovery learning adalah suatu pembelajaran dalam kelompok kecil yang dapat membimbing siswa untuk menemukan suatu konsep matematika melalui beberapa tahap, yaitu: (1) pemberian stimulus (rangsangan); (2) identifikasi masalah; (3) pengumpulan data; (4) pengolahan data; (5) pembuktian; dan (6) penarikan kesimpulan (Purwaningrum, 2016). Herdian (Purwaningrum, 2016) juga menambahkan bahwa penemuan suatu konsep dengan sendirinya oleh siswa terjadi pada pembelajaran dengan menerapkan discovery learning. Oleh karena itu, tugas guru hanyalah membimbing dan memberikan instruksi kepada siswa yang mengakibatkan pembelajaran menjadi bermakna dengan beralih dari kondisi teacher oriented ke kondisi student oriented (Kurniadi dan Purwaningrum, 2018:9).

Selain pemilihan strategi pembelajaran yang tepat, keberadaan media juga dapat berpengaruh terhadap peningkatan pemahaman matematis siswa. Dengan demikian, media dalam proses belajar mengajar mempunyai peran yang penting karena media sebagai alat perantara menyampaikan informasi atau bahan pelajaran dan sangat berpengaruh dalam kegiatan belajar mengajar. Menurut Sulistyani, dkk (2013:165) kehadiran media mempunyai arti penting dalam proses pembelajaran. Ketidakjelasan yang disampaikan oleh guru dapat dibantu dengan media sebagai sarana perantara. Kerumitan materi yang akan disampaikan kepada peserta didik dapat disederhanakan dengan bantuan media. Media juga dapat mewakili informasi yang kurang mampu diucapkan melalui kata-kata atau kalimat tertentu, bahkan keabstrakan bahan dapat dikonkretkan dengan kehadiran media dengan begitu siswa akan lebih mudah memahami materi dengan media pembelajaran. Salah satu media yaitu media cetak adalah pocket book. Pocket book digunakan sebagai alat bantu yang menyampaikan informasi tentang materi pelajaran dan lainnya yang yang bersifat satu arah, sehingga bisa mengembangkan potensi peserta didik menjadi pembelajar mandiri (Sulistyani, dkk., 2013:166). Anggraeni (2016: 9) berpendapat bahwa pocket book atau buku saku merupakan salah satu bentuk media pembelajaran cetak. Bentuknya hampir sama dengan booklet. Hanya saja pocket book ini didesain berukuran lebih kecil dan praktis sehingga bisa dibawa kemana-mana. Pembuatan Pocket book ini dirancang sedemikian rupa dengan variasi gambar, huruf dan warna yang membuat siswa termotivasi untuk membacanya dan merangsang kemampuan siswa mengeluarkan gagasan/ide yang dimiliki. Media Pocket book yang dikembangkan ini berukuran lebih kecil sehingga bisa dimasukkan dalam saku sesuai dengan namanya dan mudah dibawa kemanapun ketika siswa belajar diluar kelas maupun sekolah serta berisikan kurang dari 50 halaman bolak balik yang berisi tulisan dan gambar yang menarik. 
Berdasarkan penelitian yang dilakukan oleh Afjar, dkk (2017) diperoleh hasil bahwa media pocket book dapat memberi pengaruh positif terhadap hasil belajar siswa. Hal ini juga didukung oleh penelitian yang dilakukan oleh Sulistyani, dkk (2013) yang menyimpulkan bahwa terdapat perbedaan hasil belajar yang signifikan antara siswa yang menerima pembelajaran dengan pocket book dengan tanpa pocket book. Hal ini mengindikasikan bahwa dengan keberadaan media khususnya pocket book dapat menunjang tercapainya tujuan pembelajaran di kelas sehingga sangat penting keberadaan penggunaannya dalam proses pembelajaran di kelas. Berdasarkan paparan tersebut maka peneliti ingin melihat apakah implementasi pembelajaran menggunakan media pocketbook berbasis discovery learning dapat memberikan pengaruh sehinga tercapai tujuan yang diharapkan yaitu meningkatknya kemampuan pemahaman matematis siswa.

\section{METODE}

Penelitian ini merupakan preeksperimental designs dengan rancangan one-shot case study. Populasi penelitian adalah seluruh siswa kelas VII MTs Hidayatul Muhsinin Kabupaten Kubu Raya. Sampel diambil dengan menggunakan teknik sampling jenuh yaitu, teknik penentuan sampel bila anggota semua populasi digunakan sebagai sampel. Karena, jumlah populasi dalam penelitian ini kecil atau kurang dari 30 orang (Sugiyono, 2017: 85). Teknik pengumpulan data yang digunakan adalah metode tes untuk data kemampuan pemahaman matematis siswa dan tingkat keefektifan media pocket book.

Hasil tes kemampuan pemahaman matematis ditentukan nilai ketuntasannya baik secara individual maupun klasikal. Setelah itu hasil ketuntasan secara klasikal digunakan untuk menentukan tingkat keefektifan media pocket book dalam bentuk persentase. Adapun kriteria persentase keefektifan ditunjukkan pada tabel 1.
Tabel 1. Persentase Keefektifan Produk

\begin{tabular}{ll}
\hline Persentase (\%) & Kriteria Keefektifan \\
\hline $80 \%<$ skor $\leq 100 \%$ & Sangat Efektif \\
$60 \%<$ skor $\leq 80 \%$ & Efektif \\
$40 \%<$ skor $\leq 60 \%$ & Cukup Efektif \\
$20 \%<$ skor $\leq 40 \%$ & Kurang Efektif \\
$0 \%<$ skor $\leq 20 \%$ & Tidak Efektif \\
\hline
\end{tabular}

(Sumber: Riduwan 2015)

Media pocket book tergolong efektif dan dapat dimanfaatkan sebagai media pembelajaran dalam kegiatan belajar mengajar disekolah apabila skor yang diperoleh tergolong minimal cukup efektif.

\section{HASIL DAN PEMBAHASAN}

Hari pertama penelitian, peneliti memberikan pengajaran kepada siswa kelas VII dengan menerapkan pembelajaran menggunakan pocket book berbasis discovery learning. Terlihat antusias siswa dalam mengikuti pembelajaran, baik menerima materi, menemukan konsep materi, mengerjakan soal melalui fase-fase discovery learning dan mengerjakan soal latihan. Hari kedua penelitian, peneliti dan siswa membahas kembali materi yang telah didiskusikan di pocket book pada pertemuan sebelumnya.

Untuk hasil pengerjaan posttest siswa diberikan penilaian terlebih dahulu. Setelah nilai didapat, kemudian dihitung nilai ketuntasan secara individual dan klasikal. Hasil pengerjaan posttest disajikan pada tabel 2.

Berdasarkan tabel 2 diperoleh 26 siswa tuntas secara individual dikarenakan nilai posttest yang diperoleh lebih dari KKM (Kriteria Ketuntasan Minimal) yang telah ditetapkan pada mata pelajaran matematika di kelas VII MTs Hidayatul Muhsinin Kabupaten Kubu Raya yaitu 75. Setelah itu dilakukan perhitungan ketuntasan secara klasikal di kelas tersebut dan diperoleh sebesar $84 \%$ yang berarti bahwa sebagian besar siswa memiliki kemampuan pemahaman matematis yang diharapkan. 
Tabel 2. Hasil Posttest Siswa

\begin{tabular}{|c|c|c|c|c|c|c|c|}
\hline \multirow{2}{*}{$\begin{array}{l}\text { No. } \\
\text { Siswa }\end{array}$} & \multicolumn{5}{|c|}{ Skor Total } & \multirow{2}{*}{ Skor Total } & \multirow{2}{*}{ Nilai } \\
\hline & 1 & 2 & 3 & 4 & 5 & & \\
\hline 1 & 6 & 4 & 3 & 4 & 4 & 21 & 81 \\
\hline 2 & 4 & 6 & 4 & 4 & 2 & 20 & 77 \\
\hline 3 & 6 & 8 & 4 & 3 & 4 & 25 & 96 \\
\hline 4 & 4 & 6 & 2 & 2 & 3 & 17 & 65 \\
\hline 5 & 6 & 6 & 3 & 3 & 2 & 20 & 77 \\
\hline 6 & 6 & 4 & 4 & 4 & 4 & 22 & 85 \\
\hline 7 & 2 & 4 & 1 & 2 & 2 & 11 & 42 \\
\hline 8 & 6 & 8 & 4 & 4 & 2 & 24 & 92 \\
\hline 9 & 6 & 8 & 2 & 4 & 3 & 23 & 88 \\
\hline 10 & 6 & 8 & 4 & 4 & 4 & 26 & 100 \\
\hline 11 & 6 & 8 & 3 & 3 & 3 & 23 & 88 \\
\hline 12 & 6 & 6 & 3 & 4 & 3 & 22 & 85 \\
\hline 13 & 4 & 6 & 4 & 4 & 4 & 22 & 85 \\
\hline 14 & 6 & 8 & 3 & 3 & 3 & 23 & 88 \\
\hline 15 & 6 & 6 & 3 & 3 & 3 & 21 & 81 \\
\hline 16 & 4 & 4 & 2 & 2 & 2 & 14 & 54 \\
\hline 17 & 6 & 6 & 3 & 4 & 3 & 22 & 85 \\
\hline 18 & 4 & 6 & 3 & 4 & 2 & 19 & 73 \\
\hline 19 & 6 & 6 & 4 & 4 & 3 & 23 & 88 \\
\hline 20 & 6 & 8 & 2 & 4 & 4 & 24 & 92 \\
\hline 21 & 6 & 8 & 4 & 3 & 4 & 25 & 96 \\
\hline 22 & 5 & 7 & 3 & 3 & 3 & 21 & 81 \\
\hline 23 & 6 & 7 & 3 & 3 & 3 & 22 & 85 \\
\hline 24 & 4 & 8 & 2 & 4 & 2 & 20 & 77 \\
\hline 25 & 6 & 6 & 2 & 4 & 3 & 21 & 81 \\
\hline 26 & 6 & 6 & 3 & 3 & 3 & 21 & 81 \\
\hline 27 & 6 & 8 & 4 & 4 & 4 & 26 & 100 \\
\hline 28 & 5 & 4 & 3 & 4 & 4 & 20 & 77 \\
\hline 29 & 4 & 8 & 3 & 3 & 4 & 22 & 85 \\
\hline 30 & 4 & 6 & 4 & 3 & 4 & 21 & 81 \\
\hline \multirow[t]{2}{*}{31} & 4 & 4 & 2 & 4 & 2 & 16 & 61 \\
\hline & \multicolumn{5}{|c|}{ Jumlah } & & 2.527 \\
\hline
\end{tabular}

Langkah selanjutnya adalah menentukan keefektifan dari pocket book yaitu dilihat dari nilai hasil pengerjaan posttest siswa. Hasil pengerjaan siswa ditentukan persentase keefektifannya. Adapun kriteria persentase keefektifan dilihat dari rumus berikut.

Persentasi Indeks

$(\%) \quad=$ jumlah nilai siswa $\geq K K M$ (75) Jumlah Siswa

Setelah dilakukan perhitungan diperoleh nilai persentase sebesar $84 \%$ dan tergolong sangat efektif.

Hasil penelitian ini sejalan dengan hasil penelitian yang dilakukan oleh Istiana, dkk 
(2015) yang menyimpulkan bahwa penerapan model Discovery Learning dapat meningkatkan aktivitas dan prestasi belajar siswa. Demikian juga dengan penelitian yang dilakukan oleh Kurniadi dan Purwaningrum (2018) yang menyatakan bahwa pembelajaran melalui discovery learning berbantuan asesmen hands on activities dapat dijadikan sebagai alternatif pembelajaran matematika untuk meningkatkan kemampuan pemahaman matematis siswa. Penelitian yang dilakukan oleh Moreno (2018) menghasilkan kesimpulan yang serupa yaitu penerapan pembelajaran dengan model discovery learning dapat memperbaiki proses pembelajaran dan dapat meningkatkan kemampuan pemahaman matematis peserta didik. Begitu pula penelitian yang dilakukan oleh In'am dan Hajar (2017) menyimpulkan bahwa "the results of student's learning in geometry during the implementation for this learning using the Discovery Learning with Scientific approach may said to be very good". Hal ini menunjukkan bahwa penerapan discovery learning dalam pembelajaran khususnya matematika dapat meningkatkan kemampuan pemahaman matematis peserta didik ditambah lagi dalam penelitian ini menggunakan media pocket book berbasis discovery learning yang dapat memudahkan peserta didik dalam mengikuti proses pembelajaran di kelas yang berimbas pada tercapainya peningkatan kemampuan pemahaman matematis peserta didik itu sendiri.

\section{SIMPULAN}

Berdasarkan analisis data dari penelitian yang dilakukan serta mengacu pada perumusan masalah pada penelitian ini, dapat disimpulkan bahwa: (1) kemampuan pemahaman matematis siswa setelah diimplementasikan pembelajaran menggunakan media pocketbook berbasis discovery learning tuntas secara klasikal; (2) Pengembangan media pocket book berbasis discovery learning terhadap kemampuan pemahaman matematis pada materi aritmetika sosial kelas VII MTs Hidayatul Musinin Kabupaten Kubu Raya mencapai tingkat keefektifan dengan kriteria sangat efektif.

\section{DAFTAR PUSTAKA}

Afjar, A.M., Sabdin, A.K., \& Farhan, A. 2017. Pengaruh Media Pocket Book dalam Pembelajaran Fisika terhadap Hasil Belajar Siswa pada Materi Gelombang Stasioner Kelas XII IA MAN 3 Banda Aceh. Prosiding Seminar Nasional MIPA III. pp. 265269.

Anggraeni, Y. 2016. Pengembangan Media Pembelajaran Berbentuk Pocket Book Untuk Meningkatkan Motivasi Belajar Siswa Pada Mata Pelajaran Praktik Akuntansi Manual (PAM) Kelas XI Akutansi SMK YPKK 1 Sleman Daerah Istimewa Yogyakarta: Universitas Negeri Yogyakarta.

Anitah, S. 2009. Teknologi Pembelajaran. Surakarta: Yuma Pustaka.

In'am, A., \& Hajar, S. 2017. Learning Geometry through Discovery Learning Using a Scientific Approach. International Journal of Instruction. Vol. 10, no. 1, pp. 55-70.

Istiana, G.A., Catur, A.N., \& Sukardjo, J.S. 2015. Penerapan Model Pembelajaran Discovery Learning untuk Meningkatkan Aktivitas dan Prestasi Belajar Pokok Bahasan Larutan Penyangga pada Siswa Kelas XI IPA Semester II SMA Negeri 1 Ngemplak Tahun Pelajaran 2013/2014. Jurnal Pendidikan Kimia (JPK). Vol. 4, no. 2, hlm. 65-73.

Karim, A. 2011. Penerapan Metode Penemuan Terbimbing dalam Pembelajaran Matematika untuk Meningkatkan Pemahaman Konsep dan Kemampuan Berpikir Kritis Siswa Sekolah Dasar. Jurnal Edisi Khusus, 1, 21-32.

Kurniadi, G., \& Purwaningrum, J.P. 2018. Kemampuan Pemahaman Matematis Siswa melalui Discovery Learning 
Berbantuan Assesment Hands on Activities. Jurnal Ilmiah Pendidikan Matematika ANARGYA. Vol. 1, no. 1, hlm. 8-13.

Moreno, L. 2018. Penerapan Metode Discovery Learning untuk Meningkatkan Kemampuan Pemahaman Matematis Siswa Kelas VII SMPN 25 Pekanbaru. Jurnal Pendidikan Tambusai. Vol. 2, no.6, hlm. 1401-1428.

NCTM. 2000. Principles and Standards for School Mathematics. Reston, VA: National Council of Teacher Mathematics.

Purwaningrum, J. P. 2016. Mengembangkan Kemampuan Berpikir Kreatif Matematis melalui Discovery Learning Berbasis Scientific Approach. Refleksi Edukatika. Vol. 6, no. 2, hlm. 145-157.

Purwaningrum. J. P. 2016. Pengaruh Problem-Based Learning "What's Another Way" dan Discovery Learning dalam Meningkatkan
Kemampuan Berpikir Kreatif Matematis Siswa SMP. JES-MAT. Vol. 2, no. 2, hlm. 53-66.

Putra, D.H., Setiawan, H., Nurdianti, D., Retta, I., \& Desi, A. 2018. Kemampuan Pemahaman Matematis Siswa SMP di Bandung Barat. JPPM. Vol. 11, no.1, hlm. 19-30.

Riduwan. 2015. Belajar Mudah Penelitian. Bandung: Alfabeta.

Sugiyono. 2017. Metode Penelitian

Kuantitatif, Kualitatif, dan $R \& D$. Bandung: Alfabeta.

Sulistyani, N.H.D., Jamzuri., \& Rahardjo, D.T. 2013. Perbedaan Hasil Belajar Siswa antara Menggunakan Media Pocket Book dan tanpa Pocket Book pada Materi Kinematika Gerak Melingkar Kelas X. Jurnal Pendidikan Fisika. Vol. 1, no. 1, hlm. 164-172.

Zulkardi. 2003. Pendidikan Matematika di Indonesia: Beberapa Permasalahan dan Upaya Penyelesaian. Palembang: Universitas Sriwijaya. 